\title{
Our Hantaan Virus Became a New Family, Hantaviridae in the Classification of Order Bunyavirales. It will Remain as a History of Virology
}

\author{
Ho Wang Lee ${ }^{1,2 *}$ and Jin Won Song ${ }^{2}$ \\ ${ }^{1}$ The National Academy of Sciences, Republic of Korea \\ ${ }^{2}$ Department of Microbiology, College of Medicine, Korea University, Seoul, Korea
}

\section{Corresponding}

Ho Wang Lee, M.D., Ph.D.

Department of Microbiology, College of Medicine, Korea University, Inchon-ro 73, Seongbuk-gu, Seoul 02841, Korea

Phone : +82-2-2286-1336

Fax : $+82-2-923-3645$

Received : May 30, 2019

Revised : June 14, 2019

Accepted : June 17, 2019

No potential conflict of interest relevant to this article was reported.

Copyright (C) 2019 Journal of Bacteriology and Virology

(C) This is an Open Access article distributed under the terms of the Creative Commons Attribution Non-Commercial License (http://creativecommons.org/ license/by-nc/3.0/).
In February 2019, the order Bunyavirales, previously family Bunyaviridae, was amended by new order of 10 families including Hantaviridae family, and now accepted by the International Committee on Taxonomy of Viruses (ICTV). Hantaviridae is now a family of the order Bunyavirales, and the prototype virus species is Hantaan orthohantavirus. The family Hantaviridae is divided into four subfamilies including Mammantavirinae, Repantavirinae, Actantavirinae and Agantavirinae. The subfamily Mammantavirinae is divided into four genera including Orthohantavirus, Loanvirus, Mobatvirus and Thottimvirus. The four Hantavirus species have been found in Korea including three Orthohantaviruses (Hantaan orthohantavirus, Seoul orthohantavirus and Jeju orthohantavirus) and one Thottimvirus (Imjin thottimvirus).

Key Words: order Bunyavirales, family Hantaviridae, genus Orthohantavirus, genus Thottimvirus, Hantaan orthohantanvirus, Seoul orthohantanvirus and Jeju orthohantanvirus, Imjin thottimvirus

한탄강의 기적: 한탄바이러스와 서울바이러스 발견

호랑이는 죽어서 가죽을 남기고 사람은 죽어서 이름을 남긴다(虎死留皮 人死留名)라는 말을 나는 어려서부터 많이 들으면서 자라났다.

우리가 사는 지구상에는 생명력이 있는 생물과 동물 그리고 생명력이 없는 돌과 철 같은 광물 등이 있는데 동물만이 두뇌를 가지고 살고 있다. 두뇌를 가진 동물 중에서 인간의 두뇌가 가장 크고 발달하면서 살아가고 있기 때문에 인간을 만물의 영장이라 고도 한다.

인간이 지구상에서 살아오면서 언제나 처음보는 동물·식물과 광물은 이름을 붙여 다른 것과 구별해 왔으며 그 대표적인 것이 새로 탄생한 아기에게 새로운 이름을 지어 다른 아 기들과 구별하는 것이었다.

나는 대학을 졸업하고 미생물학을 전공해 왔는데 그 중에서도 눈에 보이지 않는 작은 여과성 미생물로 병을 일으키는 바이러스를 연구하기 시작했다. 그 이유는 눈에 보이 지 않는 바이러스들이 사망률이 높은 무서운 전염병의 원인이라는 사실을 알고 있기 때문에 보통 사람들은 연구하기 싫어하였기 때문이다. 바이러스의 특징은 눈에 보이지 않을 정도로 크기가 작으며 특히 바이러스 자신이 분열하여 증식하지 못하기 때문에 다른 세포에 들어가 그 세포가 자기와 똑같은 바이러스를 만들어 내기 때문에 나는 
흥미를 느끼고 연구하기 시작하였다.

이런 특이한 성질 때문에 바이러스학이 발달하지 못하고 있다가 전자현미경이 생기고 또 1950년대 초 Enders 등이 원숭이의 신 장상피세표를 시험관벽에서 배양하는 기술을 개발하고 이 세포에서 소아마비바이러스를 배양할 수 있는 새로운 기술을 발표한 후 바이러스학이 급속히 발전하기 시작하였고 Enders는 이 논문으로 노벨상을 받았다.

내가 1955년 미국에 유학갔을 때가 바이러스학의 꽃이 피기 시작한 때였으며, 나는 그때 Minnesota 대학에서 바이러스학을 전 공하기 시작하였고, 우리나라의 무서운 전염병인 일본뇌염바이러스의 연구로 석사와 박사학위를 받고 1960년 초 서울대학교 의 과대학으로 돌아왔다. 그리고 1954 1959년까지 미국의 $\mathrm{NIH}$ 연구비로 한국에서 뇌염바이러스의 월동기전연구를 하였는데, 일본 뇌염바이러스의 예방백신이 1967년에 일본에서 개발된 후 나는 1969년에 뇌염연구를 중지하고 새로운 연구과제를 찾기 시작하 였다.

한국전쟁이 시작되고 1년 후인 1951년 봄 중부전선에서 중공군과 전투중인 UN군의 미군병사 중에서 원인을 알 수 없는 괴질이 발생하였다. 그 당시 한국군은 동부전전에서 인민군과 싸우고 있었으며 중부전선과 서부전선에서는 UN군과 중공군이 전투를 하 고 있었다. 그런데 중부전선의 철원, 김화지역에서 전투중인 미군병사들이 괴질에 걸려 사망하였는데 그런 괴질환자는 미군병사 중에서만 계속 많이 발생하여 미군군의관들은 처음 보는 이 괴질을 한국형출혈열이라 명명하였으며 1954년 휴전 협정이 체결될 때까지 3,200 여명의 괴질환자가 발생하고 사망률이 $10 \%$ 를 넘었다. 미국은 한국형출혈열이라는 괴질이 소련과 중공군의 세균전 일지도 모른다는 의심을 가지고 “한국형출혈열연구반"이라는 세계최대의 연구반을 200 여명의 미국의 우수한 과학자들로 구성하고 한국, 일본, 미국 등지에서 4년간 4천만불의 연구비를 투자하고 연구하였으나 실패하고 1956년 연구를 중지하고 한국에서 철수 하였다.

1954년 여름 한국전쟁이 휴전에 들어간 후에는 중부전선의 철원, 김화지역뿐만 아니라 휴전선 이남의 한국군과 농민들이 이 괴 질에 걸려 사망하면서 한국 최대의 전염병으로 등장하게 된다.

미국이 총동원하여 연구하였으나 실패한 이 병의 원인을 누가 발견할 수 있겠단 말인가. 또 한국형 출혈열과 유사한 괴질이 제 2 차 세 계대전중 일본군과 소련군에서도 각각 만여명이 발생하여 인간실험까지 하고도 실패한 이 괴질의 원인을 누가 발견할 수 있단 말 인가.

1955 1970년까지 서방세계에서는 이런 분위기였으나 미국 NIH전염병연구소에서는 Eubenger 라는 과학자에게 미국해군대령의 계급장을 달고 동경 근처에 있는 미군연구소인 406 의학연구소에서 1965 1970년 5년간 조직배양한 Vero세포(원숭이신장상피 세포)를 가지고 한국과 일본을 오가면서 출혈열의 병원체 연구를 하였으나 그 사람도 실패하였다.

이상은 내가 하고 싶은 말의 배경을 설명한 것인데 만일 내가 이 괴질의 새로운 병원체를 발견한다면 그 병원체의 이름과 그 후 에 야기되는 여러 가지 문제, 다시 말하면 그 병원체의 운명이 어떻게 되어갔는지를 우리 바이러스학회 회원님들에게 자세히 설 명하고 싶어서 이 글을 여기에 쓰기로 한 것이다.

1969년 나는 연구비를 조달하기 위한 새로운 연구과제를 선택하여 일본에 있는 미국육군의학연구사령부 극동지부에 "한국형출혈 열 연구”라는 제목으로 연구비 지원신청서를 제출하였다. 그 당시 이 병은 소련과 중국 등 공산국가에서 많이 발생하고 있었으나 자유진영에서는 한국에서만 이 병이 유행하고 있었으며 한국에는 UN군이 가족과 같이 주둔하고 있었다. 한국군과 휴전선 근처의 주민들이 이 병에 시달리고 있었고 나는 언제든지 출혈열환자를 한국군 육군병원과 서울대학병원 내과에서 만날 수 있었고 또 연 구재료도 얻을 수 있었다.

출혈열환자 발생지역은 의정부시 교외, 동두천, 연천, 김화지구 등 서울에서 자동차로 약 한두 시간 내외의 거리에 있었다. 나는 그 당시 미국에서 일본뇌염바이러스연구로 박사학위를 받았고 우수한 논문을 두 편이나 발표한 조직배양세포의 전문가로 평이 나 있었다. 나는 1970 1976년까지 6년간 한국에서 어려운 연구 끝에 마침내 기적같이 한국형 출혈열의 병원체를 세계 최초로 발견 하였다 (1). 
그리하여 나는 1976년 봄 한국형출혈열의 병원체를 세계 최초로 발견하였다고 서울에서 발표한 후 병원체의 이름을 짓기 시작하 였다.

1976년 5월, 우리는 동두천시 송내리에서 잡은 등줄쥐의 폐장과 신장에서 출혈열환자의 회복기혈청 중에 있는 특이한 항체와 특 이하게 반응하는 항원을 간접 형광항체법으로 세계 최초로 발견하고 혈청학적 진단법을 새로이 완성하였다.

발견당시에는 이 새로운 항원이 죽은 미생물인지 또는 살아있는 바이러스인지를 알 수 없었다. 1976년 6월부터 새로운 항원이 있 는 등줄쥐의 폐장과 신장의 $10 \%$ 조직부유액을 각종 실험동물에 접종하고 항원의 증식 여부를 조사하였으나 실패하였다. 나는 새 로운 항원을 Korea 항원이라 명명하고 다른 것과 구별하였다. 그리하여 흰마우스, 흰랏드, 토끼 등 흔히 실험에 사용하는 동물의 피하근육내에 Korea 항원의 $10 \%$ 부유액을 접종하였으나 실패하였다. 그리하여 환자발생지역이 아닌 서울시 근처의 야산에서 채 집한 등줄쥐 및 다른 종류의 쥐의 피하, 근육 및 뇌에 접종하고 2일 간격으로 동물을 해부하고 조사하였더니 약 일주일 전후에 등줄쥐 폐장에서만 다량의 Korea 항원을 발견할 수 있게 되었다. Korea 항원이 바이러스라는 사실을 처음으로 확인하게 된 것은 1976년 11월이었다.

나는 한국형출혈열 병원체의 이름을 생각하기 시작하였다. 우선 내 주위에 있는 사람들과 점심을 사주면서 의견을 들었다. 그들은 나의 이름, 나의 아호, 발견한 지역의 이름, 발견한 근처의 산이름, 발견한 근처의 강의 이름(한탄강), 서울을 흐르는 한강의 이름 등을 추천하였으나 도저히 결정할 수가 없었는데 1978년 1월에 Nobel 의학상을 받은 Gajdusek 박사가 나의 연구소를 방문하였다.

그 당시 미국 $\mathrm{NIH}$ 신경병연구소의 소장이 Gajdusek 박사였고 그 밑에 유명한 Gibbs 박사가 있었다. 내가 1976년 겨울에 미육군 전염병연구소에 가서 Hantaan virus 발견강연을 한 후 $\mathrm{NIH}$ 의 Gibbs 박사가 나를 NIH에 초청하여 강의를 한 다음 그가 나보고 최고의 대우를 해주겠으니 $\mathrm{NIH}$ 에 오라고 제의했으나 나는 그 제의를 거절하였다. 그런데 그 당시 Gajdusek 박사는 New Guinea 에 출장가서 부재중이었다. 한국 전쟁 때 Gajdusek 박사는 군에 소집되어 미국 육군 대위계급장을 달고 한국 의정부에 있는 미 육군 한국형 출혈열 연구센터에서 1년 이상 출혈열 연구를 하였기 때문에 나의 연구에 관심이 많았었는데 내가 병원체를 발견하 였다고 발표하였으니 나의 연구소를 급히 찾아온 것이다. 나는 그때 그에게 출혈열병원체의 이름을 무엇으로 하면 좋을까 하고 물어보았더니 한강이야기를 끄집어 내었으나 나는 찬성하지 않았다. 그 당시 한국의 경제가 급성장하고 있어 우리 경제를 한강의 기적이라 할 때였기 때문이다. 또 한강은 서울의 중심을 흐르고 있지만 출혈열과는 아무 관련이 없었다. 내 친구의 대다수는 나의 이름에 바이러스를 붙여 ‘Howang virus'라 하라고 추천했으나 나는 동의하지 않았다. 나의 이름보다는 우리나라의 지명을 사용하 고 싶었던 것이다. 그 이유는 바이러스의 이름만 보아도 한국에서 한국인이 발견한 것을 알 수 있게 하고 싶었고 또 한국의 의학 연구 수준이 높다는 것을 세계에 알리고 싶었기 때문이다.

그리하여 동두천시 송내리에서 잡은 등줄쥐에서 병원바이러스를 발견하였기 때문에 그 근처에 있는 한탄강의 이름을 따서 한탄바 이러스로 하기로 결정하였다. 그리고 동시에 나의 아호를 漢難(한탄) 이라 하였던 것이다. 영문으로 Hantaan virus라 하였는데 Hantaan 에 a자가 두 개 있어야 미국사람이나 영국사람이 한탄이라고 정확하게 발음하였기 때문이었다.

이렇게 1976년에 등줄쥐에서 발견한 바이러스는 한탄바이러스로 명명하고 국제기구에 등록되었고 또 1980년에 서울시내에서 잡은 집쥐에서 발견한 제2의 출혈열 병원체는 서울바이러스 (Seoul virus) 라고 명명하고 국제기구에 정식으로 등록하였다(2).

이 두 개의 바이러스가 우리나라에서 한국인에 의해 발견된 최초의 바이러스이며 출혈열의 병원체인 것이다. 이 두 개의 바이러 스는 아주 배양하기 까다로운 바이러스이며 조직 배양세포에서 증식은 하나 세포를 파괴하는 병원성이 없기 때문에 조직 세포배 양에 경험이 많지 않은 사람은 배양하기 어렵고 또 실험용 쥐에서 바이러스를 배양하고 분리할 수도 없으며 등줄쥐에서만 증식하 는 특이한 바이러스이다. 내가 발견한 두 개의 바이러스의 이름의 유래를 자세히 설명하면 다음과 같다.

\section{한탄바이러스 (Genus Orthohantavirus Species Hantaan orthohantavirus)}

1976년 봄 동두천시 송내리에서 잡은 등줄쥐의 폐장과 신장에서 발견, 동두천시 북방에 있는 한탄강의 이름을 땄는데 이 강은 38선을 따라 흐르고 있기 때문에 한국전쟁이 일어나기 전에는 북조선에서 자유를 찾아 서울로 오는 사람들이 한탄강을 건너 와야 만 했다. 많은 피난민이 이 강을 건너면서 소련군과 인민군의 총에 맞아 희생되었고 강을 무사히 넘어온 사람은 자유를 찾을 수 있었던 것이다 (1). 


\section{서울바이러스 (Genus Orthohantavirus Species Seoul orthohantavirus)}

1981년 가을 서울시 마포구에 있는 큰 아파트의 경비원이 사무실에 들어 온 집쥐를 막대기로 때려 잡고 3일 후에 심한 독감의 증상으로 종로구에 있는 병원에 입원하였다. 그 환자는 집쥐를 잡았기 때문에 병이 생겼다고 강력히 주장하였기 때문에 나는 그 환자를 만나 그의 이야기를 직접 들은 후 그의 아파트의 지하에 있는 식품상가에서 잡은 집쥐에서 한탄바이러스와 유사한 새로운 바이러스를 발견하였는데 이 바이러스는 한탄바이러스와 성질이 다르며 집쥐에서만 증식하는 새로운 바이러스이기 때문에 서울시 의 이름을 따서 서울바이러스라 명명한 것이다 (2).

내가 새로이 개발한 한탄바이러스 분리용 검사방법은 간접면역형광항체법이라고 하는데 환자의 혈액 중에 있는 항체를 이용하여 형광현미경 하에서만 찾을 수 있는 아주 예민하고 복잡한 새로운 검사법이다. 우리가 한탄바이러스와 서울바이러스를 발견한 후 세계 여러 나라의 과학자들이 이 방법을 이용하여 자기 나라의 야서류에서 한탄바이러스와 유사한 바이러스를 많이 분리하였으며 특히 PCR기법을 이용하여 한탄바이러스의 친척벌에 해당하는 바이러스들을 35 개나 분리하였다.

그리하여 현재까지 새로이 발견되고 보고한 바이러스의 수는 37 개나 된다. 내가 1976년 유행성출혈열의 병원체를 세계 최초로 발견하고 한탄바이러스라 명명한 후, 국내에서 임진바이러스(Imjin thottimvirus)와 제주바이러스(Jeju orthohantavirus)를 비롯하여 세계 여러나라에서 한탄바이러스와 유사한 바이러스가 여러 가지 종류의 들쥐, 식충목 동물, 파충류, 어류 및 식물에서 너무나 많 이 발견되어 최근에 국제바이러스명명위원회 International Committee on Taxonomy of Virus (ICTV)에서 330개에 달하는 지구 상의 모든 바이러스의 생화학적 성분과 유전자를 비교검토한 후 2017년부터 바이러스들을 재분류하기 시작하여 2019년 2월에 새로 명명된 바이러스들을 전부 합쳐 새로 분류한 바이러스 분류표를 발표하였다 $(3,4,5)$. 한탄바이러스가 새로운 분류방법에 의 해 작성된 분류표에는 새로운 과(Family)를 형성하였으며 한탄바이러스의 이름을 딴 새로운 Hantaviridae Family가 생겨난 것이다. 그 과정을 살펴보면 다음과 같다.

1976년 Hantaan virus (종의 이름, Species)

1986년 Hantavirus (새로운 속의 이름, Genus)

2019년 Hantaviridae (새로운 과의 이름, Family)

한탄바이러스 발견 10년 후에 8개의 유사한 바이러스가 발견되어 새로운 속(Genus)이 생기고 그 후 37개의 Hantavirus 들이 발 견되어 새로운 과(Family)가 생긴 것이다. 1976년에 새로운 바이러스가 발견되고 43년 후에 37개의 한타바이러스가 발견되어 2019년 2월에 Hantaviridae란 새로운 과(Family)가 탄생하게 된 것이다 (5).

Hantaan virus $\rightarrow$ Hantavirus $\rightarrow$ Hantaviridae

바이러스학에서 바이러스를 분류하면 Bunyavirales 라는 목(Order) 밑에 10개의 과(Family)가 있다. 그 중에 Hantaviridae 라는 과가 생겼으며 그중에 대표적인 바이러스가 Hantaan virus로 정해진 것이다. 국제바이러스분류위원회가 발표한 Fig. 1은 바이러스 학의 분류를 나타내고 있는데 Bunyavirales 라는 목 (Order) 밑에 10개의 과(Family)가 있으며 제일 위에 Hantaviridae가 있고 대표적인 종 (Species)이 Hantaan orthohantavirus 인 것이다.

국제바이러스명명위원회 International Committee on Taxonomy of Virus (ICTV)가 1987년 Canada의 Edmonton 회의에서 Hantaan virus의 genus 이름을 Hantavirus 로 하자는 제의를 하여 받아들어지고 2016년에 헝가리 Budapest에서 개최된 ICTV 회의에서 Hantaviridae 라는 새로운 Family 이름과 Orthohantavirus 라는 종(Species)의 이름을 제청하고 공표하였다.

그리고 2018년에 Washington에서 개최된 ICTV에서 Hantaviridae 라는 Family 이름과 Orthohantavirus 라는 Species 이름이 새로이 제청되고 2019년 2월에 이상의 제청이 접수되고 공표된 것이다. ICTV내의 Hantaviridae Study Group 위원들의 명단은 다음과 같다. Maes, Piet (위원장, Belgium), Calisher, Charles H. (USA), Fulhorst, Charles F. (USA), Klempa, Boris (Slovakia), Klingström, Jonas (Sweden), Laenen, Lies (Belgium), Song, Jin-Won (송진원, South Korea), Zhāng, Yŏngzhèn (张永振, China).

한국에 있는 의학자들이나 바이러스학자들은 일반적으로 상기한 국제위원회에 참석하지 않기 때문에 그 변화를 잘 알지 못하는 경우가 많다. 그러나 지금은 모든 것이 email로 순식간에 세계의 어느 곳에든지 갈수 있기 때문에 누구든지 쉽게 알 수가 있다. 


\author{
Virus classification \\ (unranked): Virus \\ Realm: Riboviria \\ Phylum: Negarnaviricota \\ Class: Ellioviricetes \\ Order: Bunyavirales
}

There are currently about 330 viruses recognised in this order.

The order Bunyavirales contains 10 families:

\title{
Families
}

- Family Hantaviridae; type species: Hantaan orthohantavirus

- Family Arenaviridae; type species: Lymphocytic choriomeningitis mammarenavirus

- Family Cruliviridae; type species: Crustacean lincruvirus

- Family Fimoviridae; type species: European mountain ash ringspot-associated emaravirus

- Family Mypoviridae; type species: Myriapod hubavirus

- Family Nairoviridae; type species: Dugbe orthonairovirus

- Family Peribunyaviridae (which contains former genus Orthobunyavirus); type species: Bunyamwera orthobunyavirus

- Family Phasmaviridae; type species: Kigluaik phantom orthophasmavirus

- Family Phenuiviridae (which contains former genus Phlebovirus); type species: Rift Valley fever phlebovirus

- Family Wupedeviridae; type species: Millipede wumivirus

Figure 1. Virus classification of Bunyavirales

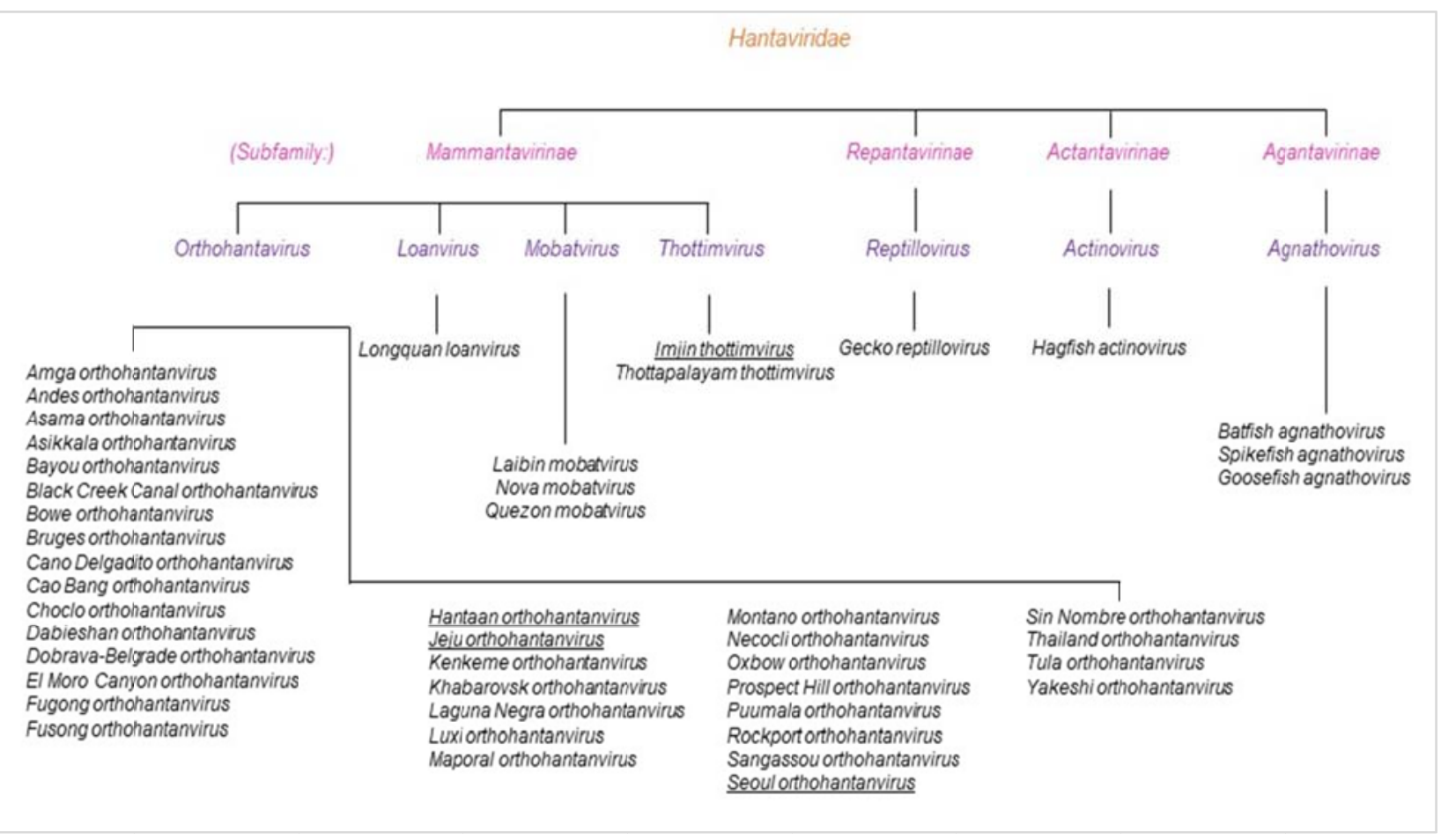

Figure 2. Virus classification of Hantaviridae

Fig. 2는 최근에 발표된 Hantaviridae Family 속에 포함한 4개 Subfamily의 바이러스들과 과거에 Hantavirus Genus 속에 있던 바이러스들을 새로운 분류법에 따라 Orthohantavirus 라는 Species 이름하에 37개의 Hantavirus를 알파벳 순으로 나열한 것이다. 
과거에 쓰던 Hantavirus 속에는 Hantaan, Seoul, Puumala와 Sin Nombre virus 4개만 포함되어 있었는데 이번 분류에는 Hantaan 앞에 Orthohantavirus 라는 긴 단어가 붙어있어 복잡하고 발음하기도 어렵고 보기도 싫지만 할 수 없다.

Ortho란 단어는 정확하다 또는 죠 이란 의미로 쓰이는 접두사인데 모든 Hantavirus 앞에 붙어있으니 너무 복잡한 것 같은 생각 이 들지만 할 수가 없다.

이상은 새로 편성된 바이러스의 분류에 대하여 설명하였는데 나는 애국적인 학자였기 때문인지 한국에서 한국과학자가 세계최초 로 미국학자, 일본학자, 러시아학자, 중국학자 그리고 구라파학자들이 하지 못한 일을 해냈으며 대한민국의 서울이란 도시와 한탄 강이란 강의 이름이 붙은 바이러스가 바이러스학 역사뿐만 아니라 세계 과학의 역사에도 남아있게 되었다는 사실을 정말로 자랑 하고 싶었기 때문에 존경하고 사랑하는 대한바이러스학회 회원님들에게 알리고 바이러스학회의 기록에도 남기고 싶었던 것이다. 한국의 한탄바이러스는 영원히 의학 역사책에 남아있을 것이다.

국제바이러스명명위원회 International Committee on Taxonomy of Virus (ICTV)는 2019년 2월 다음과 같이 새로운 바이러스 분 류 및 명명에 대한 역사적 배경을 발표하였다 (Fig. 3). 2016년 Budapest에서 개최된 ICTV에서 이때까지 사용한 Byunyaviridae 는 최근 발견된 많은 바이러스들을 포함하지 못하였기 때문에 전에 Bunyaviridae Family에 속했던 5개의 Genus, 즉 Hantavirus, Nairovirus, Orthobunyavirus, Phlebovirus 및 Topsovirus을 새로운 Family로 승격하여 기존의 5개의 Family와 합쳤다. 새로운 10 개의 Family는 Fig. 1과 같다.

\section{ICTV Taxonomy history: Orthohantavirus \\ Bunyavirales $>$ Hantaviridae $>$ Orthohantavirus}

$$
\begin{aligned}
& \text { 2018b EC 50, Washington, DC, July 2018; } \\
& \text { Email ratification Februrary } 2019 \text { (MSL \#34) }
\end{aligned}
$$

\section{Moved}

Riboviria $>$ Negarnaviricota $>$ Polyploviricotina $>$ Elioviricetes $>$ Bunyavirales $>$

Hantaviridae $>$ Mammantavirinae $>$ Orthohantavirus

$2018 \mathrm{a}$

EC 50, Washington, DC, July 2018;

Email ratification October 2018 (MSL \#33)

Moved

Negarnaviricota $>$ Polyploviricotina $>$ Elioviricetes $>$ Bunyavirales $>$

Hantaviridae $>$ Orthohantavirus

2016

EC 48, Budapest, Hungary, August 2016;

Email ratification October 2017 (MSL \#31)

\section{Renamed, Moved}

Bunyavirales $>$ Hantaviridae $>$ Orthohantavirus

1987 Plenary session vote 12 August 1987 in Ednonton (MSL \#10)

New

Bunyaviridae $>$ Hantavirus

Figure 3. Taxonomy history of Orthohantavirus from International Committee on Taxonomy of Virus (ICTV)

Baltimore Classification에서의 Bunyavirales Order밑에 있던 5개의 Families는 negative-sense singlle stranded RNA를 유전체로 보유하고 있는 enveloped RNA viruses였으며, 주로 절지동물이나 설치류에서 발견되었고 이 Order안의 viruses들은 사람과 식물 에 감염한다.

Bunyaviruses의 대부분은 절지동물 매개성이었으나 Hantaviruses는 그렇지 않고 설치류의 대변이나 공기전염을 통해 감염된다. 
상기한 여러 과정을 보면 1976년 한탄바이러스가 발견된 후 이와 유사한 바이러스들이 한국에서는 서울바이러스, 임진바이러스 및 제주바이러스가 Finland에서는 Puumala virus 그리고 1993년에 미국에서 Sin Nombre virus와 New York virus가 발견되고 최 근까지 37 개의 Hantavirus 가 발견되면서 바이러스의 재편성, 재분류 및 새명명의 필요성이 야기되었던 것이다. 현재까지 330종의 바 이러스가 바이러스학 속에 있으며 그 중 37개가 Hantavirus 속에 있었으니 새로운 개혁이 일어날 수밖에 없었다.

1976년 내가 발견한 Hantaan 바이러스가 다른 바이러스와 질과 성격 및 전파경로 등이 전혀 다르기 때문에 바이러스들을 새로이 개 편할 수밖에 없게 되었던 것이다.

결론적으로 한국인의 아호 漢漢些 딴, 또 한국의 한탄강의 이름을 딴 한탄바이러스가 새로운 바이러스학의 Family 의 이름 Hantaviridae로 등장할 수 밖에 없었던 것이다.

새로운 한타바이러스: 임진바이러스와 제주바이러스 발견

저자는 미국국립보건원에서 근무하였던 1994년에 미국 동부 로드 아일랜드 (Rhode Island) 주에서 한타바이러스폐증후군으로 사 망한 환자의 병원체인 뉴욕바이러스(New York virus)를 뉴욕 주의 Shelter Island에서 채집된 흰발생쥐 (white-footed mouse)로 부터 분리, 발견하여 Lancet 저널에 보고하였다.

토타팔라얌바이러스 (Thottapalayam virus)는 1964년 인도 남부에 서식하는 식충목 포유류 사향뒤쥐(musk shrew)에서 일본뇌염 을 연구하던 중 우연히 발견되어 그 정체를 모르고 있었다가 1980년대 후반에서야 전자현미경 소견으로 한타바이러스의 일종일 가능성이 제기되었다. 저자가 1993년부터 미국국립보건원에서 한타바이러스 연구를 진행할 그때까지 토타팔라얌바이러스의 극히 짧은 염기서열만 밝혀진 상태였다. 그 당시 토타팔라얌바이러스의 동물실험은 진행했었고, 추가적인 염기서열을 밝혀내고자 하였 으나 염기서열 규명에는 성공하지 못했다. 그 후 2005년에 미국 하와이의대에 방문교수로 가 있던 중 토타팔라얌바이러스 전장 유전체 염기서열을 었는데 성공하여 1990년대 얻은 동물실험결과와 같이 토타팔라얌바이러스가 식충목 동물인 땃쥐 (insectivore shrew) 매개 한타바이러스의 표준형임을 보고하였다.

그리고 고려대학교로 돌아온 후 국내 서식하고 있던 식충목 동물에서 한타바이러스 연구를 계속하여 임진바이러스와 제주바이러 스를 발견하였다. 새로운 속명(genus)인 "Thottimvirus"의 명칭은 Thottapalayam virus의 "Thott"와 Imjin virus의 "Im"을 합쳐서 2019년 ICTV에서 만들어졌다.

\section{임진 바이러스 (Genus Thottimvirus Species Imjin thottimvirus)}

국내에서 채집된 식충목 동물에서 신종 한타바이러스를 찾는 연구를 진행하던 중 비무장지대(DMZ) 근처에 서식하는 식충목 동물 인 우수리땃쥐 (Ussuri white-toothed shrew, Crocidura lasiura)에서 신종 한타바이러스를 발견하고 분리하였다. 우수리땃쥐는 검 은색 또는 갈회색 털을 가진 식충목의 땃쥐과 포유동물로 한반도 전역과 중국 북동부, 시베리아 남동부 등에 서식한다. 새 바이러 스는 채집지역 인근의 임진강 이름을 따서 임진바이러스로 명명하였고 2007년 학계에 발표하였다 (3). 이 임진바이러스는 토타팔 라얌바이러스와는 유전자 염기서열이 $70 \%$ 정도 유사한 반면 설치류에서 분리된 기존의 한타바이러스들과는 유사성이 약 $40 \%$ 에 그치는 것으로 확인되어 새로운 종의 한타바이러스임을 확인하였다. 혈청학적인 검사를 통해서도 임진바이러스는 한탄바이러스, 푸말라바이러스, 뉴욕바이러스와는 거의 항체교차반응을 보이지 않았고, 토토팔라얌바이러스와도 높지 않은 교차반응을 보임으로 써 기존의 한타바이러스와는 혈청학적으로 다른 신종 한타바이러스임을 확인하였다. 이후 경기도의 다양한 지역에서 임진바이러 스가 발견되었고, 계통학적으로 유전적 다양성이 크다는 것을 보여주었다. 임진바이러스가 사람에게 감염을 일으켜 병을 일으키는 지에 대해서는 향후 더 연구가 필요하다.

\section{제주바이러스 (Genus Orthohantavirus Species Jeju orthohantavirus)}

우수리땃쥐에서 임진바이러스의 발견은 국내 땃쥐매개 한타바이러스 연구를 계속하게 해주었다. 5년간 제주도 전역에서 채집된 작 은땃쥐(Asian lesser white-toothed shrew, Crocidura shantungensis) 조직으로부터 한타바이러스 속에 속하는 신종 바이러스를 중합효소 연쇄반응법(PCR)을 이용해 최초로 발견한 것이다. 작은땃쥐는 제주도를 포함한 한반도·몽골·극동 러시아 및 중국 북동부 
지역에 폭 넓게 서식하는 식충목 동물로, 2012년 본 연구팀은 그전까지 한타바이러스가 발견되지 않았던 청정지역 제주도에서 신 종 한타바이러스를 발견하여 제주바이러스 라고 명명을 하였다(4). 제주바이러스의 전체 L, M 및 S분절 유전자 염기서열을 분석 한 결과, 이 바이러스는 2009년에 우수리땃쥐에서 발견된 임진바이러스와는 유전자 계통분류학상 전혀 다른 신종 한타바이러스 인 것으로 밝혀졌다. 또한 제주바이러스는 식충목류 한타바이러스가 아닌 설치류 한타바이러스와 같은 공통조상을 보임으로써 기 존의 땃쥐 유래 한타바이러스와는 다른 특징을 보여주었다. 제주바이러스의 향후 연구를 위해서는 바이러스 분리 등의 연구가 계 속 진행되어야 한다.

\section{REFERENCES}

1) Lee HW, Lee PW, Johnson KM. Isolation of the etiologic agent of Korean hemorrhagic fever. J Infect Dis 1978;137:298-308

2) Lee HW, Baek LJ, Johnson KM. Isolation of Hantaan virus, the etiologic agent of Korean hemorrhagic fever from wild urban rats. J Infect Dis 1982;146:638-44.

3) Song JW, Kang HJ, Gu SH, Moon SS, Bennett SN, Song KJ, et al. Characterization of Imjin Virus, A Newly Isolated Hantavirus from the Ussuri White-Toothed Shrew (Crocidura lasiura). J Virol 2009;83:6184-91.

4) Arai S, Gu SH, Baek LJ, Tabara K, Bennett SN, Oh HS, et al. Divergent ancestral lineages of newfound hantaviruses harbored by phylogenetically related crocidurine shrew species in Korea. Virology 2012:424:99-105.

5) Maes $P$, Adkins S, Alkhovsky SV, Avšič-Županc T, Ballinger MJ, Bente DA, et al. Taxonomy of the order Bunyavirales: second update 2018. Arch Virol 2019;164:927-41. 